\title{
Implementasi Algoritma Squeezer dan Term Frequency Ranking dalam Pembangunan Sistem Rekomendasi Tempat Makan
}

\author{
Vincentius Wirawan ${ }^{1}$, Seng Hansun ${ }^{1}$, Hargyo Tri Nugroho I. ${ }^{2}$ \\ ${ }^{1}$ Program Studi Teknik Informatika, Universitas Multimedia Nusantara, Tangerang, Indonesia \\ vincentius.wirawan@yahoo.com, hansun@umn.ac.id \\ ${ }^{2}$ Program Studi Sistem Komputer, Universitas Multimedia Nusantara, Tangerang, Indonesia \\ hargyo@gmail.com
}

Diterima 15 Maret 2014

Disetujui 19 Juni 2014

\begin{abstract}
Food is something that can not be separated from the life of every human being. Its variation makes a lot of people interested in tasting many types of food, even they have not known yet. The detail information of restaurants, especially their location could be a problem. So, the restaurants recommendation website is made to help them. The recommendations are given by the Squeezer algorithm using the user's input as references. The accuracy of the given recommendations are determined from the amount and consistency of the user at the time of selecting the item. The Term Frequency Ranking is used as a searching feature to display the search results in ordered manner by their relevancy rank. Experiment result shows that the Term Frequency Ranking gives high value of Recall, 1 , and 0.46 for the Precision value.
\end{abstract}

Index Terms-Recommended System, Squeezer, Term Frequency Ranking, Website.

\section{PENDAHULUAN}

Makanan merupakan suatu hal yang tidak dapat dilepaskan dari kehidupan setiap manusia. Keanekaragaman jenis makanan membuat banyak orang tertarik untuk mencicipi banyak jenis makanan, bahkan yang mereka belum ketahui. Kadang, tidak semua daerah memiliki semua jenis makanan. Ada beberapa daerah yang memiliki jenis makanan tertentu. Hal ini membuat para pecinta makanan berjelajah ke daerah-daerah tertentu untuk menikmati makananmakanan yang berada di daerah tersebut.

Dalam hal ini, tentunya banyak orang yang tidak mengetahui informasi lengkap tentang tempat makan pada suatu daerah tersebut seperti jenis makanan, harga, bahkan lokasinya. Hal ini menjadi acuan dibuatnya banyak situs untuk berbagi informasi tentang tempat makan. Banyak orang dapat mencari dengan mudah informasi-informasi tentang makanan apa saja yang berada pada daerah yang dituju.

Akan tetapi, masih banyak situs-situs yang tidak memiliki sistem rekomendasi bagi pengunjung dalam memberikan rekomendasi makanan yang mungkin sejenis dan lebih baik, yang user belum tahu. Melalui keterbatasan ini, muncullah ide untuk membuat website sistem rekomendasi tempat makan, sehingga dapat memuaskan pengalaman user (user experience) dalam mencari informasi dan rekomendasi tentang makanan apa saja yang terdapat di suatu daerah yang akan atau sedang dikunjunginya.

Sistem rekomendasi tersebut menggunakan prefensi penggunanya sendiri sebagai acuan. Sistem akan mencatat jejak pencarian dan pemilihan makanan-makanan yang dicari, kemudian memberikan rekomendasi tempat makan yang memiliki kesamaan dengan yang dipilih oleh user, atau bahkan lebih baik dari perkiraan user sendiri.

Dari pemaparan di atas, maka dirancanglah sistem rekomendasi tempat makan berbasis web dengan algoritma Squeezer yang dapat membantu memberikan rekomendasi tempat makan terhadap pengguna web tersebut berdasarkan kriteria dari makanan yang dicari atau sedang dilihat. Sistem ini juga menggunakan metode Term Frequency Ranking yang dapat membantu memberikan rekomendasi tempat makan berdasarkan kata pencarian (keyword) dari user dengan memberikan rekomendasi tempat makan yang memiliki keterkaitan dan diurutkan berdasarkan hasil yang memiliki keterkaitan paling tinggi ke paling rendah.

Penelitian ini merupakan pengembangan dari penelitian tentang algoritma Squeezer sebelumnya, yang berjudul "Penerapan Algoritma Squeezer untuk Memberikan Rekomendasi Pilihan Lagu Berdasarkan Daftar Lagu yang Dimainkan pada Pemutar Mp3 Android" oleh Eko Wahyu Wibowo, Siti Rochimah, dan Abdul Munif. Pada penelitian sebelumnya, algoritma Squeezer diuji coba pada kumpulan data yang sudah ada. Pada penelitian ini, algoritma Squeezer digunakan untuk membaca atau merekam perilaku dan input dari user. Sampai saat ini, belum ditemukan penelitian serupa tentang sistem rekomendasi tempat 
makan. Diharapkan penelitian ini dapat menjadi acuan dan materi yang berguna bagi penelitian selanjutnya.

\section{LANDASAN TEORI}

\section{A. Algoritma Squeezer}

Squeezer merupakan sebuah algoritma yang digunakan untuk mengelompokkan data (clustering) sekumpulan data bertipe kategorikal [1]. Ide dasar dari algoritma tersebut sangat sederhana. Squeezer secara berulang membaca tiap pasangan data (tuple) dari kumpulan data satu persatu. Saat pasangan data pertama dibaca, akan dibuat kelompok data (cluster) baru. Pasangan data berikutnya dimasukkan ke dalam kelompok data yang sudah ada atau ditolak oleh semua kelompok yang ada, sehingga membentuk kelompok baru berdasarkan fungsi kemiripan yang diberikan antara kelompok dengan pasangan data.

Berikut adalah definisi yang digunakan dalam algoritma Squeezer. Misal A1, ..., Am adalah himpunan kategorikal atribut dengan domain D1,..., Dm berturut-turut. Misal himpunan data D adalah himpunan dari pasangan data dimana setiap pasangan data $t: t \in D^{\prime \prime} \quad x \quad \ldots . x$ Dm ". Misal TID adalah himpunan dari ID unik dari setiap pasangan data. Untuk setiap tid $\in$ TID, nilai atribut A1 dari pasangan data yang bersangkutan direpresentasikan sebagai $\operatorname{val}(\mathrm{tid}, \mathrm{Ai})$.

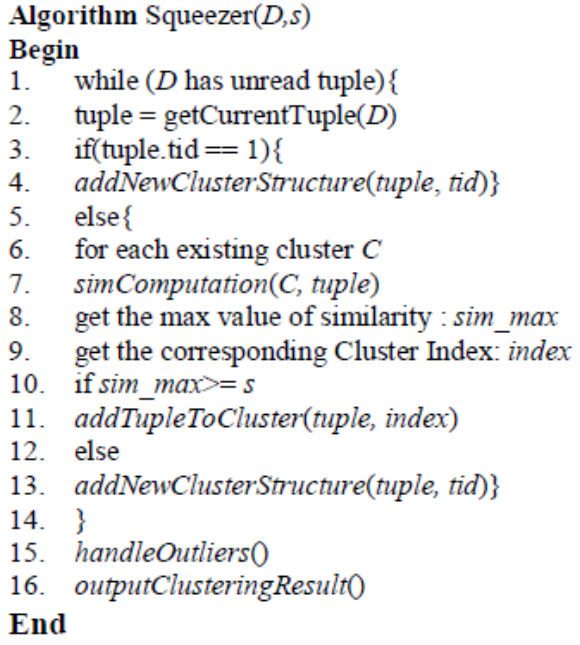

Gambar 1. Algoritma Squeezer

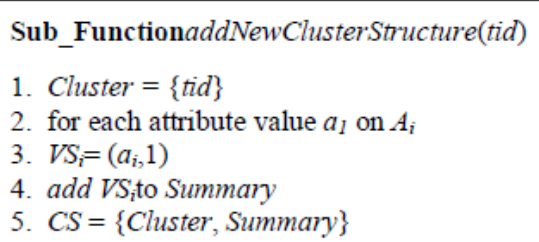

Gambar 2. Sub-fungsi addNewClusterStructure()

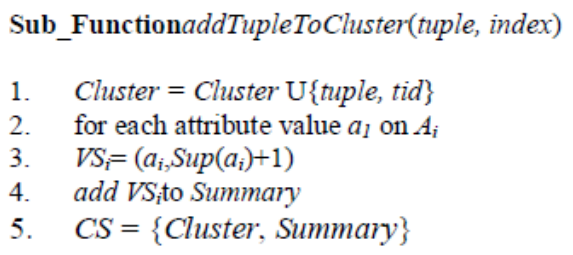

Gambar 3. Sub-fungsi addTupleToCluster()

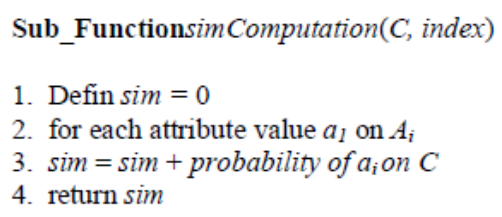

Gambar 4. Sub-fungsi simComputation()

\section{B. Ranking Model}

Untuk menetapkan peringkat dari sebuah dokumen, dilakukan pemberian skor terhadap setiap dokumen sebagai estimasi relevansi dokumen dengan query atau kata pencari yang diberikan [2]. Pembobotan dan ranking dapat diuji nilai efektifitasnya dengan mengukur nilai Precision dan Recall. Precision adalah jumlah data yang relevan yang ditemukan dibagi jumlah data yang ditemukan. Sementara Recall adalah jumlah data relevan yang ditemukan dibagi jumlah data relevan. Suatu algoritma atau metode memiliki relevansi tinggi apabila memiliki nilai precision dan recall mendekati 1 [2].

Pembobotan dalam sebuah dokumen dapat ditentukan dan dilakukan dengan tiga cara [3], yaitu :

1. Term Frequency, merupakan jumlah kemunculan suatu kata atau istilah pada dokumen atau data terkait. Secara intuitif, semakin banyak kata atau istilah yang cocok atau sesuai dengan kata pencari, maka semakin tinggi bobot dokumen tersebut yang juga mengacu semakin tinggi nilai relevansi dokumen atau data tersebut dengan kata pencari.

2. Document Frequency, merupakan jumlah banyaknya dokumen atau data dimana istilah tersebut muncul pada sebuah kumpulan data. Secara intuitif, semakin banyak data yang memiliki istilah tersebut, semakin buruk istilah tersebut sebagai diskriminator. Oleh karena itu, bobot yang diberikan pada istilah tersebut sangat kecil.

3. Document Length, merupakan istilah panjang dokumen atau data yang dapat berupa size dalam byte atau jumlah banyaknya istilah yang dikandung oleh dokumen atau data tersebut. Semakin panjang sebuah dokumen, maka istilah tersebut akan semakin sering muncul dan digunakan (memiliki frekuensi tinggi), sehingga dapat memberikan bobot yang lebih tinggi.

C. Sistem Rekomendasi

Rekomendasi adalah memberitahukan kepada seseorang atau lebih bahwa sesuatu yang dapat 
dipercaya. Dapat juga merekomendasikan diartikan sebagai menyarankan, mengajak untuk bergabung, menganjurkan suatu bentuk perintah. Sistem rekomendasi bertujuan memberikan rekomendasi item (barang-barang) baru kepada user (pengguna/calon pembeli) yang akan digunakan. Sistem rekomendasi biasanya menghasilkan daftar rekomendasi di salah satu dari dua cara yaitu melalui penyaringan kolaboratif atau berbasis konten [4]. Pendekatan kolaboratif membangun sebuah model dan perilaku masa lalu pengguna (data yang sebelumnya dipilih oleh pengguna), kemudian menggunakan data tersebut untuk memprediksi data baru yang nantinya akan direkomendasikan kepada pengguna.

Terdapat dua pendekatan utama untuk merekomendasikan item kepada user, yaitu contentbased filtering dan collaborative filtering [5].

\section{Content-Based Filtering}

Content-Based Filtering menggunakan informasiinformasi yang sudah ada sebelumnya untuk diperhitungkan kembali untuk menjadi output dalam memberikan rekomendasi. Pendekatan ini dapat memberikan rekomendasi, walaupun belum ada timbal balik atau input terlebih dahulu dari user.

\section{Collaborative Filtering}

Collaborative Filtering menggunakan timbal balik dari user terhadap sistem untuk meningkatkan kualitas materi yang diberikan kepada user. Untuk dapat memberikan rekomendasi terhadap user, user harus terlebih dahulu memberikan input atau masukkan terhadap sistem. Input dari user tersebut akan dicatat oleh sistem dan diolah menjadi data yang nantinya akan diberikan kepada user.

Untuk sistem rekomendasi tempat makan daerah ini, digunakan Collaborative-Filtering yang mengambil timbal balik dari user terhadap item yang dipilih. Kemudian dengan algoritma Squeezer diambil kriteria dari item yang dimasukkan user dan diproses.

\section{METODOLOGI DAN PERANCANGAN SISTEM}

\section{A. Metodologi Penelitian}

1. Studi Literatur

Tahap pertama penelitian ini adalah dengan melakukan studi literatur menggunakan referensi buku, artikel, jurnal, mengenai algoritma Squeezer, metode Term Frequency ranking, dan berbagai sumber untuk mendukung pembangunan dan pengembangan website. Literatur tersebut dijadikan pedoman dalam melakukan penelitian.

2. Pencarian dan Pendataan Kebutuhan

Pengumpulan data-data berupa tempat makan di kota-kota yang sudah ditentukan sebelumnya. Datadata tempat makan tersebut diberikan beberapa atribut yang merupakan kriteria makanan tersebut.
3. Perancangan Desain Website dan Database

Setelah mendapatkan semua data yang dibutuhkan, dilakukan perancangan dan pembuatan database untuk menampung semua data yang telah didapatkan. Selain itu, dilakukan juga perancangan website yang nantinya akan digunakan untuk mempresentasikan data.

4. Pembangunan Website dan Penerapan Algoritma

Melakukan pembangunan website dan implementasi algoritma Squeezer yang digunakan dalam sistem rekomendasi ini.

\section{Uji Coba}

Website yang telah jadi dan diimplementasikan dengan Algoritma Squeezer untuk sistem rekomendasinya, akan dicoba seberapa akuratnya rekomendasi yang dihasilkan oleh Algoritma Squeezer ini. Pengujian ini menggunakan beberapa skenario yang telah disusun sesuai dengan kemungkinan kemungkinan yang akan terjadi untuk melihat hasil yang dikeluarkan oleh algoritma Squeezer ini dalam pemberian rekomendasi kepada user. Pengujian terhadap metode Term Frequency Ranking dilakukan dengan memasukkan string kata pencarian dengan panjang yang bervariasi. Keakuratan dari metode Term Frequency Ranking ini dapat diukur dari nilai Precision dan Recall yang akan keluar sesuai dengan string kata pencari yang dimasukkan.

B. Perancangan Sistem

1. Diagram alir

- Diagram Alir Sub-proses Squeezer

$\rightarrow$ Diagram alir pembentukan populasi

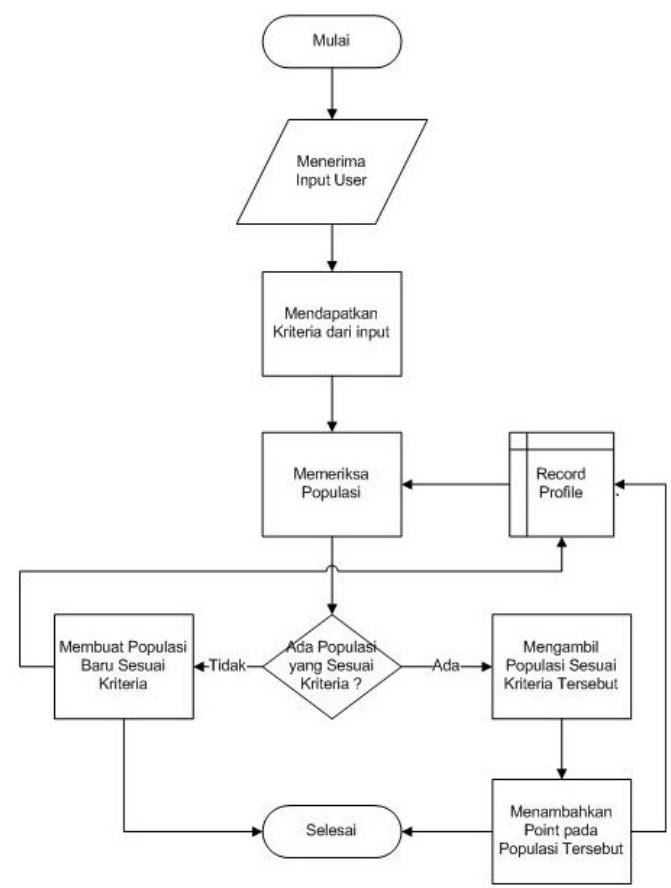

Gambar 5. Diagram alir pembentukan populasi 
Pada sub-proses ini, dimulai dari penerimaan input dari user, yaitu pilihan tempat makan. Pilihan tempat makan tersebut akan diambil kriteria yang terdapat didalamnya. Setelah itu, akan dilakukan pemeriksaan apakah terdapat populasi yang sesuai dengan kriteria tersebut. Apabila tidak terdapat populasi yang sesuai dengan kriteria tersebut, maka akan dibuatkan populasi baru yang sesuai dengan kriteria tersebut. Apabila sudah ada populasi yang sesuai dengan kriteria tersebut, maka akan ditambahkan point pada populasi tersebut.

$\rightarrow$ Diagram alir pemberian rekomendasi

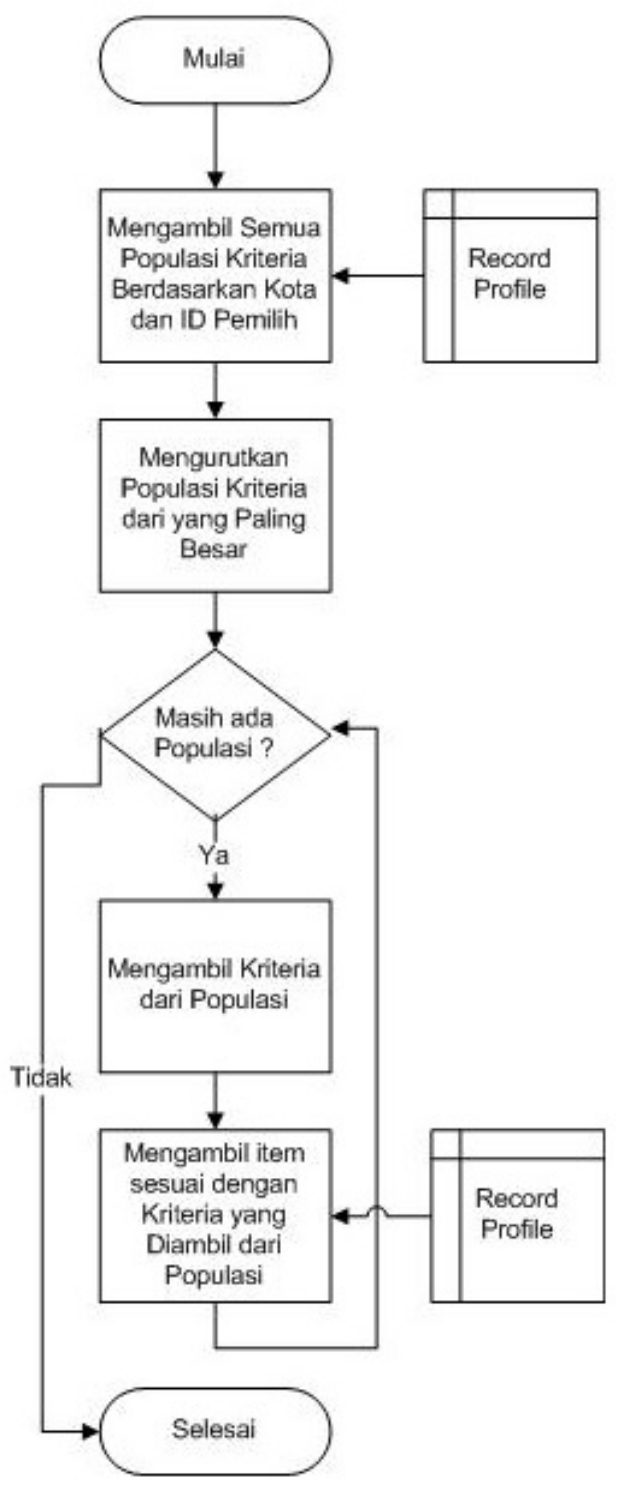

Gambar 6. Diagram alir pemberian rekomendasi

Pada bagian pemberian rekomendasi ini, dimulai dari pengambilan semua populasi kriteria yang sesuai dengan user yang sedang aktif dan kota tempat makan yang dipilih. Populasi-populasi tersebut diurutkan dari yang memiliki point paling tinggi sampai ke point yang paling rendah. Setelah itu, kriteria-kriteria pada setiap populasi akan diambil dan dijadikan acuan untuk memberikan rekomendasi kepada user, yaitu dengan cara merekomendasikan tempat makan yang memiliki kriteria yang sama dengan kriteria pada populasi tersebut.

- Diagram Alir Sub-proses Ranking

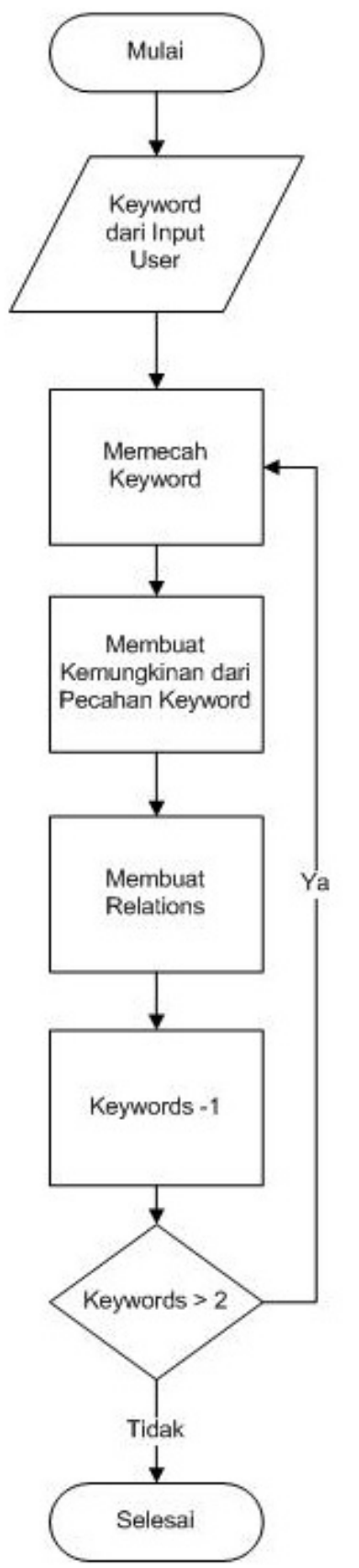

Gambar 7. Diagram alir sub-proses Ranking

Pemberian ranking untuk menentukan relevansi dokumen dimulai dengan penerimaan kalimat pencari dari user. Kalimat pencari tersebut kemudian dipecah 
menjadi kata-kata dan kemudian dilakukan dan dicari kemungkinan-kemungkinan kombinasi kata yang terbentuk. Setelah semua kemungkinan kombinasi kata terbentuk, maka jumlah panjang kata untuk kemungkinan kombinasi akan dikurangi dan dilakukan pencarian kembali kombinasinya. Data yang memiliki kata pencari yang lebih banyak didalamnya, memiliki nilai relevansi lebih tinggi. Setelah itu, dibuatlah pengurutan dari data yang memiliki relevansi paling tinggi ke yang paling rendah.

\section{Data Flow Diagram}

- DFD Algoritma Squeezer

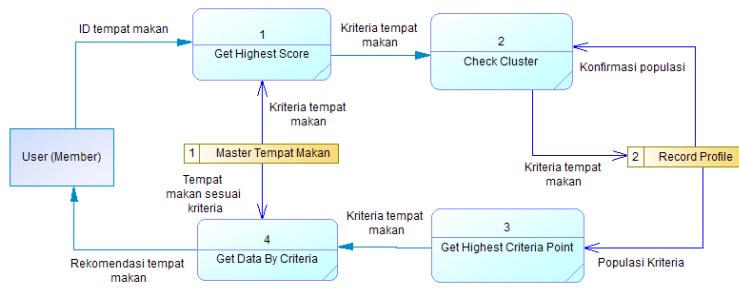

Gambar 8 . DFD Algoritma Squeezer

Pada DFD Squeezer seperti pada Gambar 8, terdapat empat proses utama pemberian rekomendasi, yaitu Get Highest Score, Check Cluster, Get Highest Criteria Point, dan Get Data by Criteria. Proses dimulai dari user yang memilih sebuah tempat makan, secara otomatis ID tempat makan tersebut dikirimkan. Kemudian, pilihan tempat makan oleh user tersebut diolah untuk diambil nilai kriteria tertingginya pada proses Get Highest Score. Setelah nilai kriteria tertingginya diperoleh, dilakukan pemeriksaan pada populasi apakah sudah ada populasi dengan kriteria yang didapat tersebut atau belum. Apabila belum ada, maka dibuat populasi baru, dan apabila sudah ada, maka ditambahkan 1 point pada populasi tersebut.

Proses selanjutnya adalah Get Highest Criteria Point dimana pemeriksaan terhadap populasi yang ada. Populasi-populasi tersebut diambil dan diurutkan berdasarkan point yang paling tinggi ke yang paling rendah. Setelah itu, dilakukan pengambilan data-data yang sesuai dengan kriteria dari populasi-populasi yang diambil untuk diberikan kepada user pada proses Get Data by Criteria.

- DFD Term Frequency Ranking



Gambar 9. DFD Term Frenquency Ranking
Proses ranking ini digunakan pada saat user memberikan kata kunci pencarian untuk mencari tempat makan yang diinginkan. Dimulai pada proses Explode String, dimana kata kunci oleh user dipecah menjadi pecahan-pecahan kata. Kemudian, pecahanpecahan kata tersebut dikirimkan ke proses Make Words Possibility untuk dibuatkan kemungkinankemungkinan kombinasi kata. Setelah semua kemungkinan kombinasi kata sudah terbentuk, maka kata-kata tersebut dijadikan query untuk melakukan penarikan dari database pada proses Create Query Graph. Kemudian hasil query tersebut diberikan kepada user pada halaman Search Result.

\section{Entity Relationship Diagram}

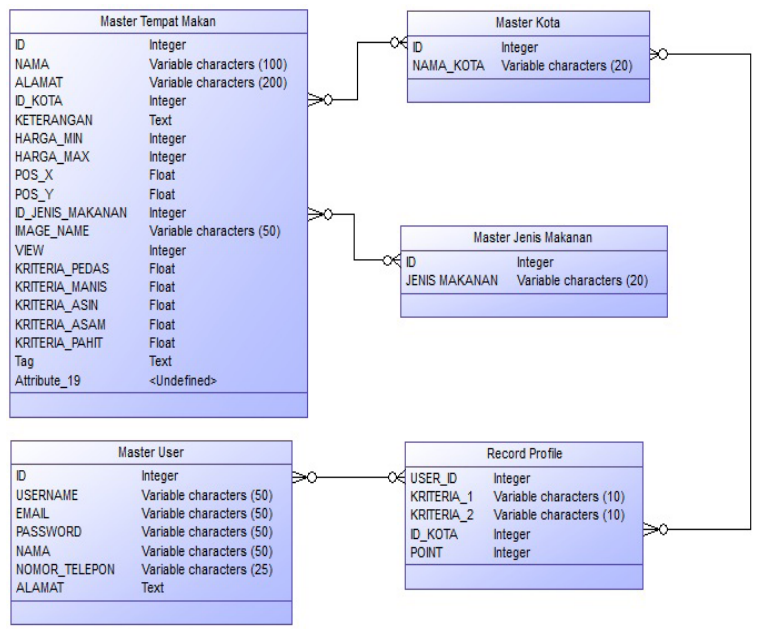

Gambar 10. Entity Relationship Diagram

C. Penerapan

1. Algoritma Squeezer

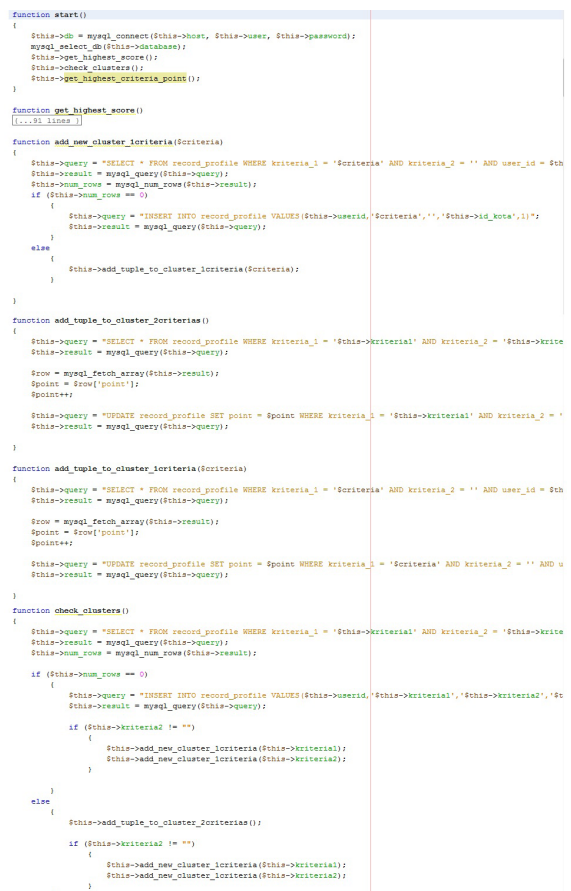

Gambar 11. Kode Sumber Algoritma Squeezer 


\section{Metode Term Frequency Ranking}

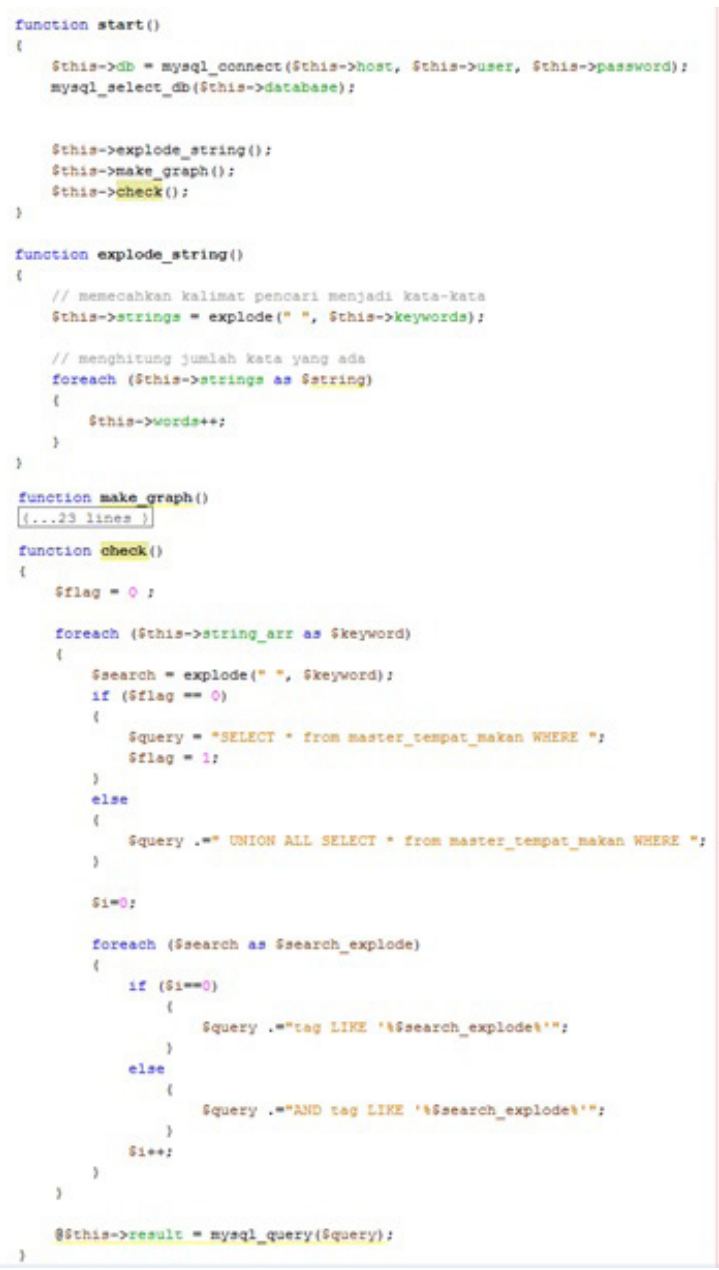

Gambar 12. Kode Sumber Metode Term Frequency Ranking

\section{UJI COBA}

A. Uji Coba Algoritma Squeezer dalam Pemberian Rekomendasi

Pengujian ini dilakukan dengan membuat empat skenario pemilihan makanan dengan perbandingan makanan yang memiliki dua kriteria dengan makanan yang memiliki satu kriteria yang berbeda.

Berikut adalah skenario-skenario pemilihan makanan dan hasil yang dikeluarkan oleh algoritma Squeezer dalam pemberian rekomendasi :

1) 1 kriteria $=0,2$ kriteria $=15$

\begin{tabular}{|c|c|c|c|c|c|c|c|}
\hline \multirow{2}{*}{ Percobaan } & \multirow{2}{*}{\multicolumn{2}{|c|}{ Pilihan }} & \multicolumn{2}{|c|}{ Populasi (User) } & \multicolumn{2}{|c|}{ 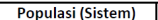 } & \multirow[b]{2}{*}{ Kesimpulan } \\
\hline & & & Kriteria & \begin{tabular}{|l|} 
Point \\
\end{tabular} & Kriteria & Point & \\
\hline \multirow{10}{*}{15} & pedas-manis & pedas - manis & pedas - manis & & pedas & 13 & \multirow{10}{*}{ Tidak Sesua } \\
\hline & pedas - asin & manis - asin & pedas - asin & & manis & 7 & \\
\hline & pedas - asin & pedas - pahit & pedas - asam & & pedas - manis & 5 & \\
\hline & manis - asin & pedas - asam & pedas - pahit & & $\operatorname{asin}$ & 5 & \\
\hline & pedas - manis & pedas - manis & manis - asin & & pedas - asin & 3 & \\
\hline & pedas - asin & pedas - manis & & & pedas - asam & 3 & \\
\hline & pedas - asam & pedas - pahit & & & pedas - pahit & 2 & \\
\hline & pedas - asam & & & & manis - asin & 2 & \\
\hline & & & & & asam & 3 & \\
\hline & & & & & pahit & 2 & \\
\hline
\end{tabular}

2) 1 kriteria $=5,2$ kriteria $=10$

\begin{tabular}{|c|c|c|c|c|c|c|c|}
\hline \multirow{2}{*}{ Percobaan } & \multirow{2}{*}{\multicolumn{2}{|c|}{ Pilihan }} & \multicolumn{2}{|c|}{$\begin{array}{l}\text { Populasi (User) } \\
\end{array}$} & \multicolumn{2}{|c|}{ Populasi (Sistem) } & \multirow{2}{*}{ Kesimpulan } \\
\hline & & & Kriteria & Point & Kriteria & \begin{tabular}{|l|} 
Point \\
\end{tabular} & \\
\hline \multirow{10}{*}{15} & pedas -manis & manis & pedas - manis & & pedas & 8 & \multirow{10}{*}{ kurang sesual } \\
\hline & pedas - asin & asin & pedas - asin & & manis & 7 & \\
\hline & pedas - manis & asin & manis - asin & & asin & 5 & \\
\hline & \begin{tabular}{|l|} 
pedas - asam \\
\end{tabular} & asam & manis & & pedas - manis & 4 & \\
\hline & manis - asin & manis & asin & & pedas - asin & 7 & \\
\hline & manis - asin & & pedas - asam & & manis - asin & 2 & \\
\hline & pedas - manis & & pedas - pahit & & asam & 2 & \\
\hline & \begin{tabular}{|l} 
pedas - manis \\
\end{tabular} & & asam & & pedas - asam & 1 & \\
\hline & pedas - asin & & & & pedas - pahit & 1 & \\
\hline & pedas - pahit & & & & pahit & 1 & \\
\hline
\end{tabular}

3) 1 kriteria $=10,2$ kriteria $=5$

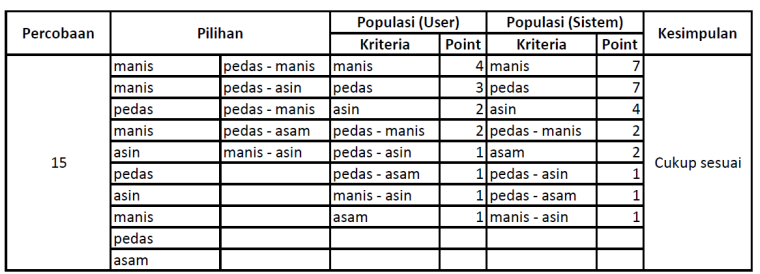

4) 1 kriteria $=15,2$ kriteria $=0$



Pada percobaan pertama (Pada tabel 1), dilakukan pemilihan 15 makanan yang semuanya memiliki dua kriteria. Hasil populasi yang diberikan oleh sistem tidak sesuai dengan populasi pilihan user yang sebenarnya. Hal ini terjadi karena pada saat pemilihan makanan yang memiliki dua kriteria, akan dibuatkan atau ditambahkan point pada kriteria yang menjadi bagiannya (penambahan point pada tiga populasi sekaligus). Sebagai contoh, untuk makanan yang memiliki kriteria pedas - manis, maka akan diberikan point pada populasi yang memiliki kriteria pedas, manis, dan pedas - manis. Hal ini dapat menyebabkan kriteria tunggal memiliki nilai tinggi karena gabungan dari makanan yang memiliki dua kriteria lainnya yang dipilih.

Sementara percobaan kedua (pada tabel 2), dilakukan pemilihan lima makanan yang memiliki satu kriteria dan 10 makanan yang memiliki dua kriteria. Hasil populasi yang dikeluarkan oleh sistem kurang sesuai dengan populasi pilihan user yang sebenarnya walaupun masih lebih baik daripada percobaan dengan skenario pemilihan 15 makanan yang memiliki dua kriteria (percobaan pertama) tadi. Hal ini karena jumlah makanan yang memiliki dua kriteria yang dipilih lebih sedikit daripada pada percobaan pertama. Hasil bias yang dikeluarkan dapat diperkecil.

Pada percobaan ketiga (pada tabel 3), dilakukan pemilihan 10 makanan yang memiliki satu kriteria dan lima makanan yang memiliki dua kriteria. Hasil populasi yang dikeluarkan oleh sistem cukup sesuai dengan populasi pilihan user yang sebenarnya. 
Terdapat tiga kriteria teratas yang sama antara populasi yang dikeluarkan oleh sistem dengan populasi pilihan user yang sebenarnya.

Sementara pada percobaan terakhir ini (pada tabel 4), dilakukan pemilihan 15 makanan yang memiliki satu kriteria. Hasil populasi yang dikeluarkan oleh sistem sesuai dengan populasi pilihan user yang sebenarnya. Hal ini dikarenakan tidak terdapat pemilihan makanan yang memiliki dua kriteria yang menyebabkan hasil yang dikeluarkan oleh sistem menjadi kurang akurat.

Dari keempat percobaan yang telah dilakukan, dapat disimpulkan bahwa jumlah kriteria makanan yang dipilih oleh user sangat mempengaruhi populasi yang dihasilkan oleh algoritma Squeezer yang digunakan untuk pemberian rekomendasi kepada user. Dengan pemilihan terhadap makanan yang memiliki dua kriteria, akan memberikan point kepada tiga populasi yang terkait sehingga dapat menyebabkan nilai populasi-populasi tersebut menjadi bias. Semakin banyak user memilih makanan dengan dua kriteria, maka rekomendasi yang diberikan akan semakin tidak sesuai.

Hal tersebut menunjukkan bahwa masih ada kelemahan terhadap algoritma Squeezer apabila hanya menggunakan kriteria makanan sebagai input dalam pembentukan populasi dan mengolahnya menjadi rekomendasi. Untuk mengatasi kelemahan tersebut, diperlukan penelitian lebih lanjut dalam penggunaan variabel - variabel lainnya seperti jenis makanan, maupun relasi antar makanan yang juga dapat digunakan sebagai acuan untuk membentuk populasi, tidak hanya populasi menurut kriteria makanan saja. Dengan pembentukan relasi antar populasi tersebut, diharapkan keakuratan dan kesesuaian rekomendasi yang dikeluarkan oleh algoritma Squeezer ini dapat menjadi lebih tinggi.

\section{B. Uji Coba Performa Metode Term Frequency Ranking}

Pengujian ini dilakukan dengan menggunakan String acak ke dalam sistem. String tersebut antara lain:
1. "angkringan"
2. "soto ayam"
3. "soto ayam jogja"
4. "nasi rames jogja"
5. "angkringan malam jogja"
6. "nasi gandul pak subur"

Berikut adalah hasil dari percobaan yang dilakukan.
Tabel 5. Tabel Hasil Pengujian metode Term Frequency Ranking

\begin{tabular}{|r|r|r|r|r|r|r|}
\hline $\begin{array}{c}\text { Percobaan } \\
\text { ke }\end{array}$ & String & $\begin{array}{c}\text { Relevan } \\
\text { Item }\end{array}$ & $\begin{array}{c}\text { Retrieved } \\
\text { Item }\end{array}$ & $\begin{array}{c}\text { Relevan } \\
\text { Collection }\end{array}$ & Precision & Recall \\
\hline 1 & 1 & 2 & 2 & 2 & 1 & 1 \\
\hline 2 & 2 & 3 & 3 & 3 & 1 & 1 \\
\hline 3 & 3 & 2 & 8 & 2 & 0.25 & 1 \\
\hline 4 & 4 & 1 & 7 & 1 & 0.14 & 1 \\
\hline 5 & 5 & 1 & 4 & 1 & 0.25 & 1 \\
\hline 6 & 6 & 1 & 8 & 1 & 0.125 & 1 \\
\hline \multicolumn{7}{|c|}{ Rata-rata } \\
\hline
\end{tabular}

Pada pengujian relevansi jawaban, metode Term Frequency Ranking ini memiliki rata-rata nilai precision dan recall sebesar 0.46 dan 1 . Pada implementasi ini, nilai yang dihasilkan tidak terlalu tinggi, dikarenakan pengambilan data diambil secara acak dan hanya memperhitungkan kata-kata yang terdapat di dalamnya. Kelemahan metode Term Frequency Ranking ini adalah hanya menampilkan hasil berdasarkan perhitungan urutan kata saja. Apabila terdapat hasil yang tidak sesuai namun memiliki urutan kata benar, maka hasil tersebut akan ditampilkan sebagai rekomendasi. Untuk mengatasi kelemahan ini, diperlukan penelitian terhadap metode lainnya untuk mem-filter output yang dihasilkan, salah satunya dengan pemeriksaan terhadap frase dari kalimat tersebut apakah benar atau tidak. Diharapkan dengan penggunaan filter tersebut dapat meningkatkan akurasi dan ketepatan rekomendasi yang dihasilkan dari metode Term Frequency Ranking ini. Namun kelebihan dari metode Term Frequency Ranking ini adalah mengurutkan item dari yang memiliki relevansi paling tinggi sampai paling rendah.

\section{SIMPULAN DAN SARAN}

\section{A. Simpulan}

Algoritma Squeezer telah berhasil diimplementasikan di dalam sistem rekomendasi tempat makan. Dari penelitian yang telah dilakukan, dapat disimpulkan bahwa rekomendasi yang dihasilkan oleh algoritma Squeezer ini sangat bergantung pada pilihan user. Semakin banyak user memilih makanan yang memiliki dua kriteria, maka rekomendasi yang diberikan semakin tidak sesuai. Hal tersebut dikarenakan pemilihan makanan yang memiliki dua kriteria akan memberikan nilai kepada tiga populasi sekaligus dan membuat perhitungan menjadi tidak tepat.

Relevansi jawaban yang diberikan dalam metode Term Frequency Ranking ini memberikan hasil yang cukup baik. Berdasarkan pengujian, metode ini memiliki tingkat recall yang tidak terlalu tinggi yaitu 1, dan precision 0.46 dimana semua item yang memiliki relevansi ditampilkan kepada user. Akan tetapi kelemahan metode ini adalah hanya menampilkan hasil yang memiliki kesesuaian dengan kata saja dan tidak melihat kesesuaian item yang direkomendasikan tersebut. Selain itu, kelebihan penggunaan metode ini 
yaitu menampilkan item dengan urutan dari item yang memiliki relevansi paling tinggi sampai paling rendah

\section{B. Saran}

Beberapa saran yang dapat diberikan untuk mengembangkan penelitian berikutnya antara lain:

1. Agar pemberian rekomendasi oleh algoritma Squeezer ini dapat lebih akurat, dapat menggunakan variabel - variabel lain seperti jenis makanan, ataupun relasi antar makanan dalam pembentukan populasi. Selain itu, perlu juga dilakukan penghubungan antar populasi dengan variabel yang berbeda dan dilakukan validasi, sehingga rekomendasi yang diberikan akan lebih akurat dan tidak mengacu pada satu variabel saja.

2. Untuk menghasilkan hasil pencarian yang lebih baik dan optimal dalam hal relevansi, disarankan menambahkan fitur filtering terhadap kalimat dari item yang direkomendasikan. Filter tersebut dapat berupa pemeriksaan frase dari kalimat, pembuangan kata yang tidak baku, dan sebagainya, sehingga dapat menampilkan hasil yang lebih sesuai dan akurat sehingga dapat meningkatkan nilai precision dan recall nya.

\section{Daftar Pustaka}

[1] Z. He, X. Xu, dan S. Deng.2002. "Squeezer:An Efficient Algorithm for Clustering Categorical Data". Journal of Computer Science and Technology, Vol. 17 No.5, (2002) 611624.

[2] Wibowo, Ari. 2011. "Pengujian Kerelevanan Sistem temu Kembali Informasi”. Seminar Nasional Ilmu Komputer 2011.

[3] Liu, F. dkk, "Effective Keyword Search in Relational Database". Proceeding ACM SIGMOD International Conference on Management of Data. Pp. 563-574.

[4] F. Ricci, L. Rokach, B. Shapira. Chapter 1: Introduction to Recommender Systems Handbook. Recommender Systems Handbook. Springer. 2011.

[5] Hosein Jafarkarimi, "A Naïve Recommendation Model for Large Databases". International Journal of Information and Education Technology. 2012.

[6] E.W Wibowo, Siti R., A. Munif.2013. "Penerapan Algoritma Squeezer untuk Memberikan Rekomendasi Pilihan Lagu Berdasarkan Daftar Lagu yang Dimainkan pada Pemutar Mp3 Android". Teknik Informatika, Fakultas Teknologi Informasi, Institut Teknologi Sepuluh Nopember (ITS), Vol. 2 No. 1, 2013. 